\title{
Sistem Kontrol Robot Sepak Bola Beroda menggunakan Finite State Machine (FSM)
}

\section{MOHAMAD BINAWAN SATRIYO, KHAIRUL ANAM, MOHAMMAD AGUNG PRAWIRA NEGARA}

\author{
Departemen Teknik Elektro, Fakultas Teknik, Universitas Jember, Indonesia \\ Email: khairul@unej.ac.id
}

Received 20 Juli 2020 | Revised 12 Agustus 2020 | Accepted 26 November 2020

\begin{abstract}
ABSTRAK
Perkembangan teknologi menuntut transisi alat yang berbasis manual menjadi otomatis. Hal ini tak terkecuali pada perkembangan robot, termasuk robot sepak bola. Robot ini mengalami perkembangan sangat pesat. Hal ini didukung dengan adanya Kontes Robot Sepak Bola Indonesia (KRSBI). Penelitian kali mengusulkan robot sepak bola beroda dengan omni-directional weel sebagai pergrakannya menggunakan Finite State Machine (FSM) sebagai metode kontrol untuk menjalankan misi yang ditentukan. Misi robot yang dikembangkan yaitu mencari bola (wander), mencari posisi lurus terhadap bola, mencari gawang, dan menendang bola. Robot ini menggunakan CMUCam5 sebagai sensor masukan untuk mendeteksi bola sebagai target bedasarkan warna dan jarak. Jarak yang digunakan yaitu antara $20 \mathrm{~cm}$ sampai $60 \mathrm{~cm}$ dengan sudut antara -40 derajat sampai 40 derajat dan intensitas cahaya antara 113 sampai 1213 lux. Implementasi FSM pada robot sepak bola beroda dengan 5 jenis percobaan mencapai tingkat keberhasilan yang bagus yaitu $86 \%$ dengan rata-rata waktu menjalankan misi 29.24 detik.
\end{abstract}

Kata kunci: CMUCam5, Finite State Machine, Omni-directional wheel, Robot Sepak Bola

\begin{abstract}
Technological development demands a transition from manual to automatic tools. It includes soccer robots that have developed so rapidly. This development is supported by the Indonesian Football Robot Contest (KRSBI). This study proposes a wheeled soccer robot with Omni-directional weel as its movement using Finite State Machine (FSM) as a control to carry out the specified mission. The mission is wandering to seek the ball, looking for a straight position to the ball, looking for the goal, and kicking the ball. This robot uses CMUCam5 as an input to detect the ball as a target based on color and distance. The distance used is between 20-60 $\mathrm{cm}$ with an angle of -40 degree to 40 degree and light intensity between 113-1213 Iux. The implementation of FSM on a wheeled soccer robot with five types of experiments achieved a good result of $86 \%$ with an average mission time of 29.24 seconds.
\end{abstract}

Keywords: CMUCam5, Finite State Machine, Omni-directional weel, Wheeledsoccer robot 


\section{PENDAHULUAN}

Perkembangan teknologi saat ini berkembang seiring dengan kebutuhan manusia yang kompleks sehingga membutuhkan suatu teknologi yang berbasis manual menjadi otomatis, salah satunya teknologi robotika (Fajar, 2017)(Haritman \& Somantri, 2009). Robot memiliki peran penting bagi kegiatan manusia di bidang kesehatan, pertanian, maupun teknologi manufaktur (Fajar, 2017). Salah satu perkembangan robot yang populer dilakukan oleh peneliti, yaitu robot sepak bola (Hartanto, dkk, 2017). Hal tersebut didukung dengan adanya kegiatan Kontes Robot Indonesia (KRI) kategori Kontes Robot Sepak Bola Indonesia (KRSBI) setiap tahunnya di Indonesia untuk menampung dan meningkatkan minat, bakat, dan kemampuan peneliti (Ardhiansyah, dkk, 2017)(Hartanto dkk,, 2017)(Pratama, dkk, 2017).

Secara umum, robot sepak bola dibagi menjadi dua kategori, yaitu humanoid dan beroda (Fiqhi \& Joni, 2018)(Pratama, dkk, 2017). Robot humanoid adalah robot yang memiliki bentuk seperti manusia dengan dua tangan, dua kaki, batang tubuh, dan kepala (Naufal , dkk, 2018). Namun, robot humanoid memiliki kekurangan di antaranya adalah kebebasan gerak, keseimbangan, dan biaya pembuatan (Fiqhi \& Joni, 2018). Oleh karena itu, robot sepak bola beroda merupakan solusi dari permasalahan penggunaan robot humanoid karena memiliki tingkat kesulitan yang lebih rendah dalam mengatur keseimbangan robot dalam melakukan misi.

Robot sepak bola memiliki misi, yaitu mencari bola, mencari gawang, menggiring bola, dan menghindari halangan (Al Tahtawi, dkk, 2016)(Yulianto \& Handoyo, 2012). Semua misi dapat dijalankan dengan menggunakan kontrol otomatis berbasis artificial intelligence (AI) yang dapat melakukan tugas sesuai dengan instruksi yang diberikan. Untuk menjalankan tugas mencari bola, gawang dan menggiring bola membutuhkan metode tracking object. Salah satu peneliti menggunakan metode thresholding pada warna bola dan gawang secara bergantian (Putra, dkk, 2018). Namun, metode tersebut tidak efektif karena berpengaruh pada perubahan intensitas cahaya dan warna putih. Hal tersebut dapat diatasi dengan menggunakan Pixy CMUCam5 untuk mendeteksi objek warna sehingga dapat memudahkan pemakaiannya (Fiqhi \& Joni, 2018).

Penggunaan robot sepak bola biasanya di lingkungan yang dinamis sehingga dibutuhkan sistem kontrol untuk menjalankan misi. Robot sepak bola memiliki banyak teknik kontrol, yaitu adaptive Q-learning, color tag identification, kalman filter algorithm, dan masih banyak lainnya. Salah satu metode lain yang digunakan adalah finite state machine (FSM). FSM merupakan model kontrol yang umum digunakan untuk merancang agen cerdas yang memiliki kelebihan pada kesederhanaan komputasinya dan kemudahan dalam pemahaman serta penggunaannya (Rizaldi, dkk, 2017). FSM menggambarkan prinsip kerja sistem dengan menggunakan tiga hal, yaitu state (keadaan), event (kejadian), dan action (aksi) (Fiqhi \& Joni, 2018)(Putra, dkk, 2018). Jika dalam loop tertutup tersebut terdapat state tidak dapat melakukan perulangan tindakan, maka akan terjadi peralihan state untuk tindakan yang berbeda. Peralihan dapat menggunakan close-loop state pada FSM dengan menggunakan sensor sebagai data feedback.

Finite state machine dalam robot sepak bola diterapkan dalam beberapa aplikasi di antaranya untuk penerapan strategi dari tim robot sepak bola dalam menyerang atau bertahan (Aleluya, dkk, 2018)(Lou, dkk, 2012), untuk wasit (Dadios \& Park, 2009)(Zhu, dkk, 2015), dan untuk kontrol navigasi dari setiap robot yang membentuk perilaku robot dalam tim sepakbola (Damas \& Lima, 2004)(Kurihara, dkk, 2004). Dari penjelasan di atas, secara teori, FSM pada robot sepakbola memang bukan hal yang baru. Namun demikian, pengembangan robot 
sepak bola dari nol dengan desain yang unik dengan komponen yang terjangkau berbasis kontrol FSM perlu digalakkan. Artikel ini menghadirkan penerapan FSM pada low-cost robot sepakbola berbasis arduino.

\section{METODE PENELITIAN}

\subsection{Desain Robot}

Robot sepak bola menggunakan tiga aktuator berupa roda omni-whee/ agar dapat bergerak bebas. Gambar 1(a) merupakan desain robot yang terdiri dari beberapa komponen utama, yaitu 1)CMUCam5; 2)LCD; 3)Mikrokontroler; 4)Omni-wheel; dan 5)Selonoid. Gambar 1(b) menunjukkan bahwa desain robot memiki jarak body robot atas dan bawah sebesar $70 \mathrm{~mm}$ dan body bawah ke lantai $10 \mathrm{~mm}$ dengan diameter body $250 \mathrm{~mm}$. Robot ini adalah bagian dari proyek bersama dengan (Suhri, 2017) dalam upaya mengembangkan robot sepak bola yang murah dan bekerja sesuai dengan desain yang diharapkan. Gambar 2 menggambarkan blok diagram sistem dengan masukan jarak $(x, y)$ antara kamera dengan bola yang dihubungkan dengan aplikasi PixyMon. Kemudian data yang di proses oleh mikrokontroller sebagai masukan metode FSM untuk melakukan misi sesuai dengan skenario yang telah ditentukan.

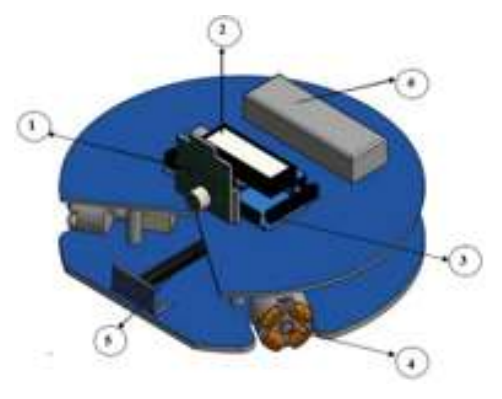

(a)

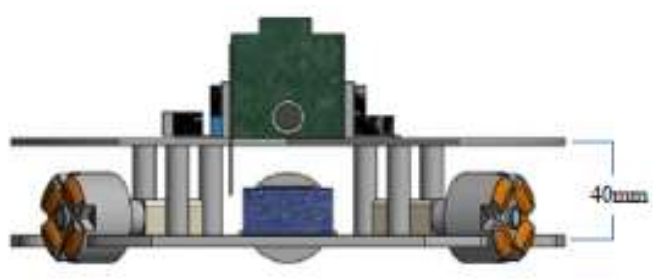

(b)

Gambar 1. Desain robot (a) tampak atas (b) tampak samping

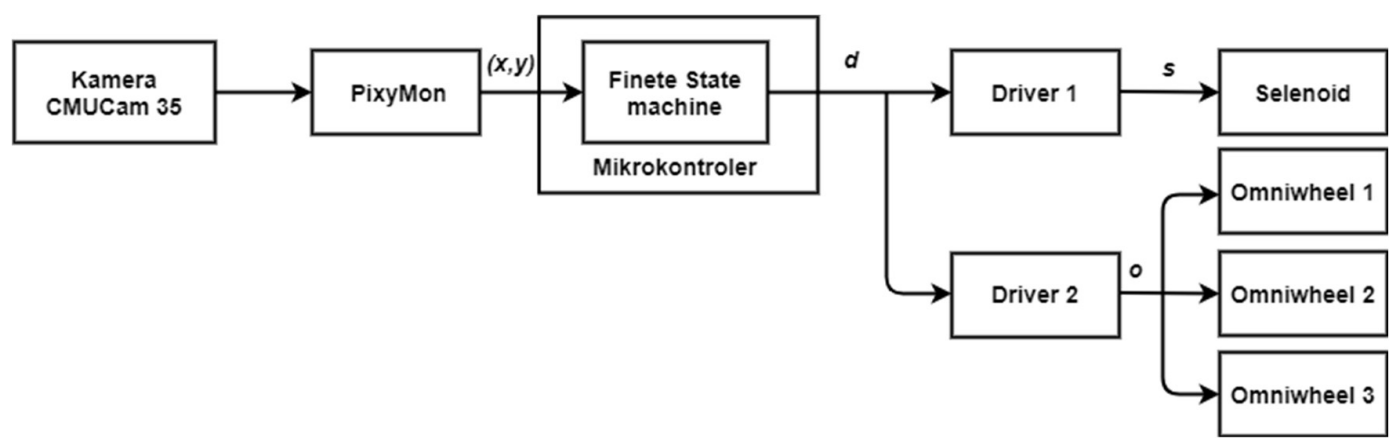

Gambar 2. Blok Diagram Sistem

\subsection{CMUCam5}

CMUCam5 merupakan sensor yang berfungsi untuk mendeteksi jarak dan sudut target berupa bola dan gawang terhadap robot. Pengaruh cahaya untuk mendeteksi target atau tracking object sangat besar sehingga diperlukan kalibrasi terhadap intensitas cahaya terhadap kondisi lingkungan yang gelap dan terang karena warna sangat sensitif terhadap intensitas cahaya (Naufal et al., 2018). Gambar 3 merupakan pengujian intensitas cahaya pada lingkungan terhadap warna bola. Hasilnya menunjukkan bahwa intensitas cahaya terbaik pada kondisi 
malam dan siang hari masing-masing sebesar \pm 113 lux dan \pm 1213 lux dengan toleransi $\pm 15 \%$ di setiap sisi lapangan.

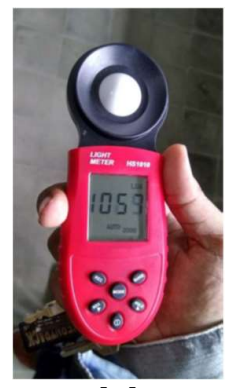

(a)

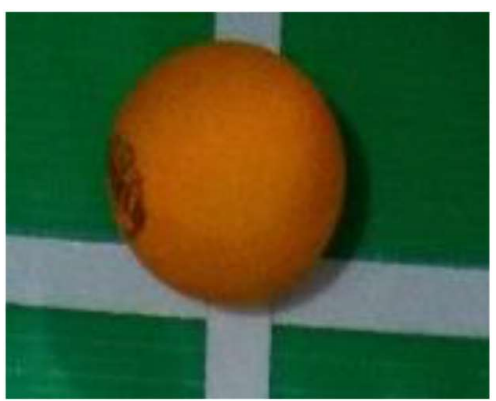

(b)

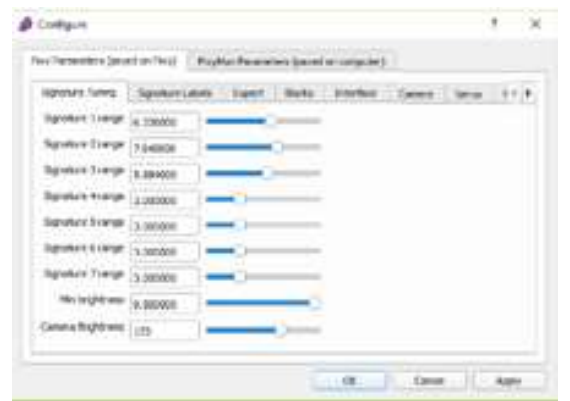

(c)

Gambar 3. Kalibrasi kamera CMUCam5 (a) pengukuran cahaya (b) bola pingpong (c) parameter warna pada PixyMon

\subsubsection{Deteksi Jarak}

Kamera CMUCam5 juga digunakan untuk mendeteksi jarak target terhadap kamera maka dibutuhkan kalibrasi. Kalibrasi deteksi jarak dengan mengukur jarak bola terhadap kamera dengan variasi jarak $20 \mathrm{~cm}, 40 \mathrm{~cm}$, dan $60 \mathrm{~cm}$ yang sudah terukur menggunakan mistar kemudian dibandingkan dengan menggunakan Persamaan (1) sampai Persamaan (5) untuk mendapatkan satuan jarak $(\mathrm{cm})$.

Pada Persamaan (1) dan (2), variabel $\mathrm{XI}_{\mathrm{c}} \mathrm{Xt}_{\mathrm{c}}$ masing-masing adalah jarak perbandingan antara lebar dan tinggi CMUCam5. $\mathrm{Xl}_{\mathrm{k}}$ dan $\mathrm{Xt}_{\mathrm{k}}$ merupakan nilai kalibrasi jarak yang digunakan, yaitu $20 \mathrm{~cm} . \mathrm{I}_{\mathrm{k}}$ dan $\mathrm{t}_{\mathrm{k}}$ adalah data lebar dan tinggi dari kamera, yaitu 42px.

$$
\begin{aligned}
& X l_{c}=\frac{l_{c} \times X l_{k}}{l_{k}} \\
& X t_{c}=\frac{t_{c} \times X t_{k}}{t_{k}}
\end{aligned}
$$

Berdasarkan hasil perhitungan dengan menggunakan Persamaan (1) dan (2) diketahui $\mathrm{XI}_{\mathrm{c}}$ dan $\mathrm{XI}_{\mathrm{t}}$ masing-masing memiliki nilai 221.05. Sehingga, nilai tersebut digunakan untuk mendapatkan nilai jarak bola terhadap kamera dengan variasi pengujian $X_{k}=[20 ; 40 ; 60] \mathrm{cm}$, dengan menggunakan Persamaan (3) dan (4). XI dan Xt masing-masing adalah lebar dan tinggi bola terhadap robot. $\mathrm{p}_{\mathrm{I}}$ dan $\mathrm{p}_{\mathrm{t}}$ masing-masing adalah lebar dan tinggi bola yang dicari. Persamaan (5) digunakan untuk mengetahui jarak bola $(x)$ terhadap robot dalam satuan $\mathrm{cm}$.

$$
\begin{aligned}
& X l=\frac{l_{k} \times X l_{k}}{p_{l}} \\
& X t=\frac{t_{k} \times X t_{k}}{p_{t}} \\
& X=\frac{X l+X t}{2}
\end{aligned}
$$

\subsubsection{Deteksi sudut}

Deteksi sudut menggunakan kamera dengan nilai koordinat $\mathrm{x}=0$ dan $\mathrm{y}=0$. Kalibrasi sudut menggunakan variasi $a=[-40 ;-30 ;-20 ;-10 ; 0 ; 10 ; 20 ; 30 ; 40]^{\circ}$. Gambar 4 merupakan ilustrasi 
kalibrasi kamera untuk deteksi sudut dengan $X_{k}=319$ dan $Y_{k}=199$. Sehingga, untuk mendapatkan nilai $a$ menggunakan Persamaan (8).

$$
\begin{aligned}
& X k=X c-\frac{319}{2} \\
& \boldsymbol{Y k}=-(X c-199) \\
& \boldsymbol{\alpha}=\frac{\arctan \left(\frac{X k}{Y k}\right)}{\mathbf{1 8 0}}
\end{aligned}
$$

\subsection{Omni-wheel}

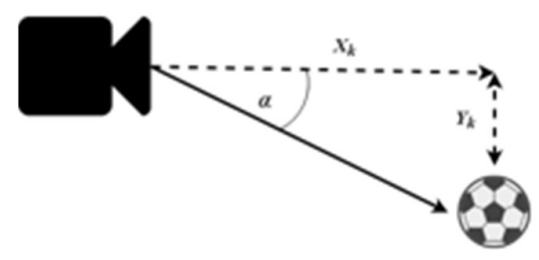

Robot sepak bola beroda dibagi menjadi dua, yaitu omni-directionaldan tidak omni-directional (Naufal et al., 2018). Omni-directional merupakan aktuator yang populer digunakan pada robot sepak bola beroda (Fajar, 2017)(Naufal et al., 2018)(Pratama et al., 2017). Konfigurasi omni-directional dari robot sepak bola beroda menggunakan simetris tiga dan empat roda omni-whee/ (Naufal et al., 2018)(Wirakusuma \& Sujono, 2018). Penelitian yang dilakukan oleh Iwan Kurnianto, dkk menggunakan omni-directional dengan menggunakan tiga omni-whee/ pada robot sepak bola karena memiliki pergerakan yang lebih bebas dan sederhana secara mekanik dan dapat bergerak secara fleksibel. Pada penelitian ini menggunakan konfigurasi gerakan robot yang digunakan, seperti pada Gambar 5.

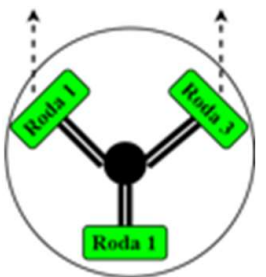

(a)

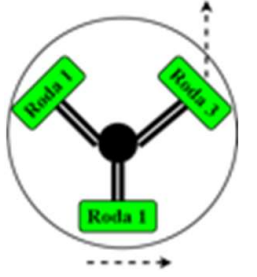

(d)

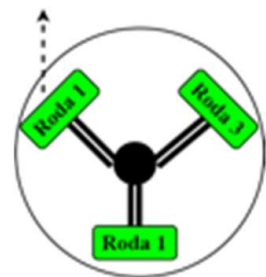

(b)

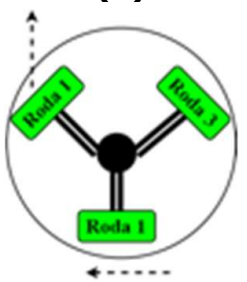

(e)

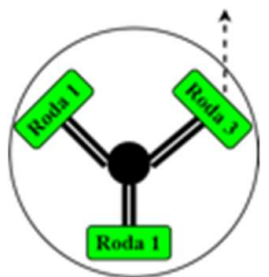

(c)

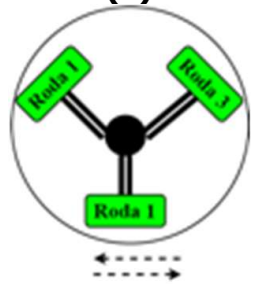

(f)

Gambar 5. Konfigurasi gerakan roda omni-wheel(a) maju (b) kanan 1 (c) kiri 1 (d) kanan 2 (e) kiri 2 (f) putar kiri atau kanan

\subsection{Finite State Machine (FSM)}

Pada dasarnya robot melakukan pergerakan sesuai dengan kontrol metode FSM. Untuk memahami metode FSM maka perlu mengetahui jumlah state, mempelajari kebijakan pada 
state individu, dan mempelajari hubungan antara masing-masing state. Gambar 6 merupakan state yang akan menjelaskan FSM pada robot menjadi beberapa state, sebagai berikut :

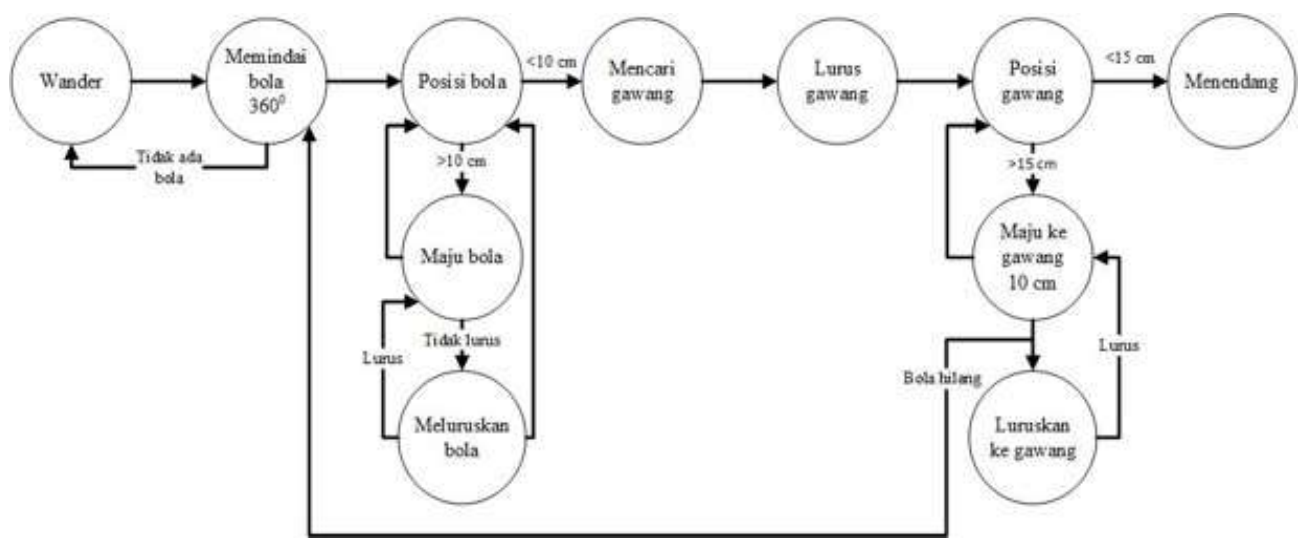

\section{Gambar 6. Diagram metode Finite State Machine (FSM)}

a. Wander adalah gerakan robot apabila robot tersebut setelah berputar $360^{\circ}$ ketika tidak mendapatkan bola, seperti pada Gambar 7. Garis warna hitam merupakan wander 1, garis warna kuning merupakan wander 2, dan garis hijau merupakan wander 3.

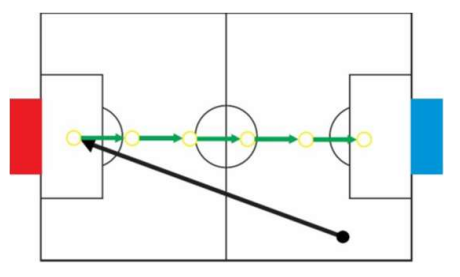

Gambar 7. Gerakan wander

b. Memindai bola adalah suatu tindakan robot untuk berputar $360^{\circ}$ dan mencari bola. Apabila tidak menemukan bola, robot akan melakukan wander. Untuk pergerakan robot memindai bola, hanya menggunakan pergerakan putar robot.

c. Posisi bola merupakan tindakan untuk menentukan keberadaan bola dengan robot. Apabila jarak robot dengan bola diatas jarak $10 \mathrm{~cm}$, maka robot akan menuju state maju bola, ketika sudah mencapai $10 \mathrm{~cm}$ maka robot akan berhenti dan menuju state mencari gawang.

d. Maju bola merupakan tindakan maju beserta melihat memindai jarak dan sudut bola. Apabila jarak bola lebih kurang dari $10 \mathrm{~cm}$, maka akan menuju state posisi bola dan apabila sudut bola tidak lurus dengan bola, maka akan menuju state luruskan bola. Sudut robot lurus dengan bola berkisar antara $-5^{0}$ dan $5^{0}$.

e. Meluruskan bola merupakan tindakan yang menggunakan pergerakan kanan satu motor dan kiri satu motor. State ini hanya untuk meluruskan bola, apabila sudut bola $-5^{0}$ maka menggunakan kanan satu motor dan apabila sudut bola $5^{0}$ maka menggunakan kiri satu motor untuk meluruskan bola.

f. Mencari gawang merupakan tindakan putar robot hingga menemukan gawang biru. Untuk mencari gawang, bola sudah disesuaikan jarak $10 \mathrm{~cm}$, sehingga ketika 
melakukan pergerakan putar robot, bola tepat berada di tengah robot hingga robot menemukan gawang biru.

g. Lurus gawang merupakan tindakan kelanjutan setelah robot menemukan gawang biru. Lurus gawang untuk menempatkan posisi gawang biru apabila akan menggiring bola, gawang tidak melebar jauh dari hadapan robot.

h. Maju ke gawang adalah berisi beberapa state posisi gawang yang sudah terdapat gerakan maju selama kurang lebih 1 detik menuju ke gawang. Pada state ini setelah robot melakukan maju, robot akan memindai bola, apabila bola masih ada dihadapan robot, maka robot akan melihat sudut gawang.

i. Luruskan ke gawang merupakan tindakan untuk meluruskan robot ke gawang pada saat robot menggirng bola.

j. Posisi gawang merupakan stateyang mengisi gerakan maju ke gawang. Tindakannya melihat jarak gawang, apabila jarak gawang lebih dari $20 \mathrm{~cm}$, maka robot akan melakukan pergerakan maju dan apabila jarak gawang sudah mencapai $20 \mathrm{~cm}$ atau kurang, maka robot akan menuju ke state menendang.

k. Menendang adalah state paling akhir pada metode ini. Tindakan yang dilakukan yaitu memberi nilai low pada solenoid, sehingga solenoid bisa mendorong bola dan memasukkan ke gawang.

\section{HASIL DAN PEMBAHASAN}

Penelitian ini fokus pada kontrol sepak bola beroda dengan konfigurasi roda omni-directional berbasis FSM, seperti pada Gambar 8. Pengujian dilakukan di lapangan robot yang digunakan pada KRSBI, seperti Gambar 9. Pengujian yang dilakukan terdiri dari kalibrasi CMUCam5, gerakan roda omni-wheel, dan implementasi FSM pada robot.

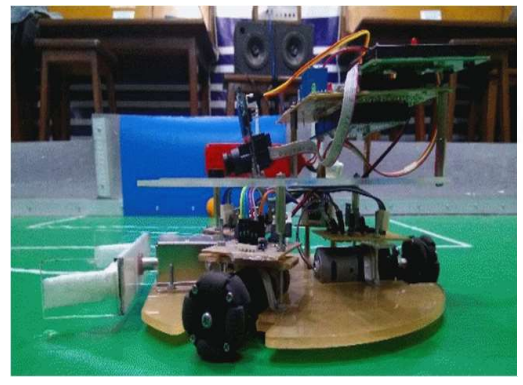

(a)

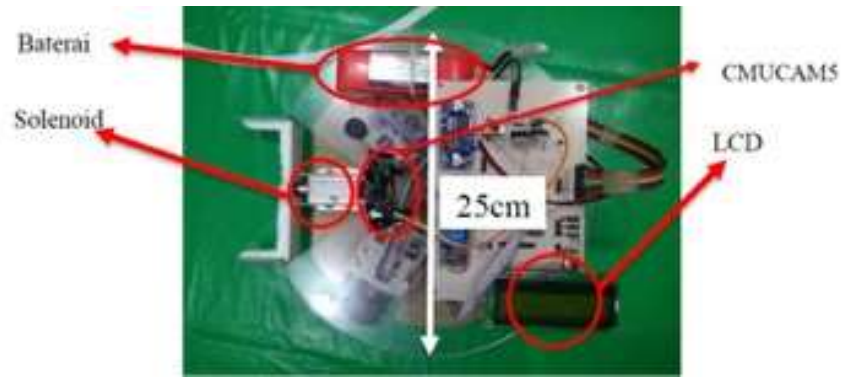

(b)

Gambar 8. Robot sepak bola (a) dari sisi samping (b) dari sisi atas

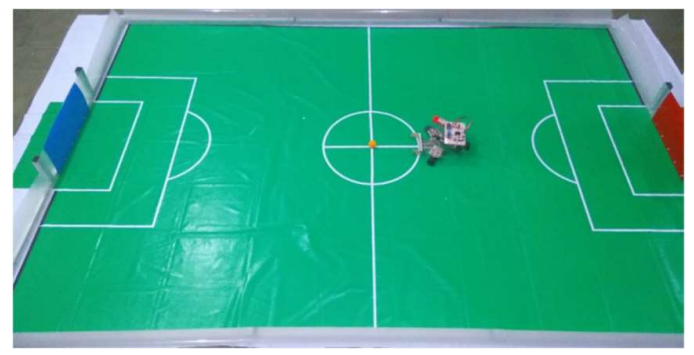

Gambar 9. Lapangan pegujian 


\subsection{Kalibrasi CMUCam5}

Pengujian pada kalibrasi CMUCam5 terdiri dari tiga pengujian, yaitu deteksi warna, deteksi jarak, dan deteksi sudut. Pengujian ini digunakan untuk mengetahui performa kamera yang dapat mendeteksi parameter warna, jarak, dan sudut objek berupa bola ping pong berwarna merah. Gambar 10 merupakan hasil percobaan kamera yang dapat mendeteksi objek benda berwarna jingga di antara objek lainnya yang berwarna selain jingga.

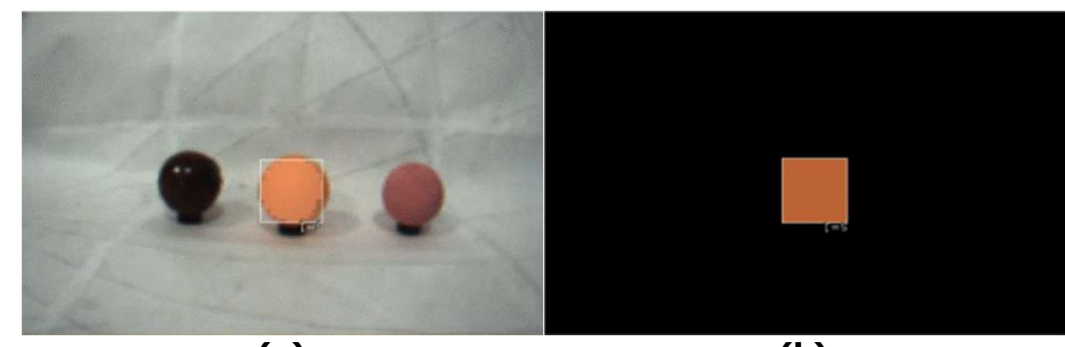

(a)

(b)

Gambar 10. Hasil deteksi kamera terhadap objek berwarna jingga (a) bola terdeteksi (b) hasil cropping warna bola

Pengujian kamera pada Gambar 11(a) digunakan untuk mendeteksi jarak. Pengujian berupa sistem kalibrasi yang diujikan terhadap variasi jarak benda terhadap robot pada dua kondisi yaitu, siang dan malam hari. Sehingga, didapatkan hasil pada Tabel 1 yang menunjukkan eror deteksi jarak $\pm 7 \%$ untuk mendeteksi jarak pada $20-60 \mathrm{~cm}$ pada siang ataupun malam hari. Maka, dapat diketahui bahwa semakin jauh jarak yang dideteksi maka semakin besar eror deteksi jarak.

Tabel 1. Kalibrasi deteksi jarak $(X)$

\begin{tabular}{|c|c|c|c|c|}
\hline \multirow{2}{*}{ Parameter Kalibrasi (cm) } & \multicolumn{2}{|c|}{ Hasil Pengujian Siang Hari } & \multicolumn{2}{c|}{ Hasil Pengujian Malam Hari } \\
\cline { 2 - 5 } & $X(\mathrm{~cm})$ & Eror $(\%)$ & $X(\mathrm{~cm})$ & Eror $(\%)$ \\
\hline 20 & 20.3 & 3.0 & 20.6 & 3.0 \\
\hline 40 & 40.35 & 5.0 & 40.9 & 5.0 \\
\hline 60 & 62.8 & 7.0 & 61.15 & 7.0 \\
\hline
\end{tabular}

Pengujian kamera selanjutnya dilakukan seperti pada Gambar 11(b) untuk mendeteksi sudut objek terhadap robot. Pengujian berupa sistem kalibrasi yang diujikan terhadap variasi posisi sudut benda terhadap robot. Tabel 2 merupakan hasil kalibrasi sudut yang nilai eror deteksi sudut $\pm 10 \%$ untuk mendeteksi sudut pada $-40^{\circ}$ hingga $40^{\circ}$ pada siang ataupun malam hari. Maka, dapat diketahui bahwa semakin besar sudut yang dideteksi maka semakin besar eror deteksi sudut.

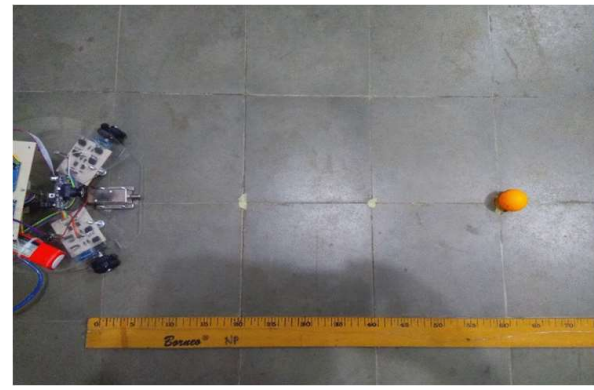

(a)

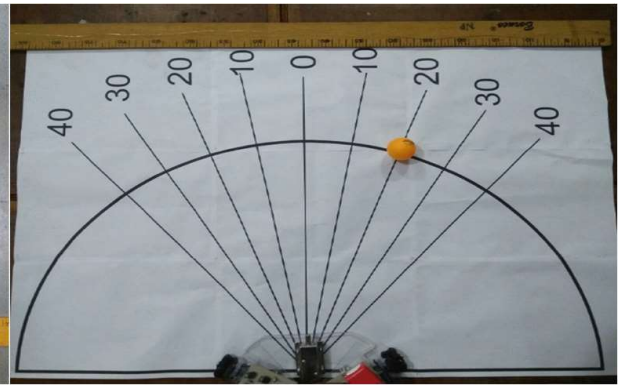

(b)

Gambar 11. Pengujian kalibrasi (a) deteksi jarak (b) deteksi sudut 
Tabel 2. Kalibrasi deteksi sudut (a)

\begin{tabular}{|c|c|c|c|c|}
\hline \multirow{2}{*}{ Parameter Kalibrasi ( $\left(^{(}\right)$} & \multicolumn{2}{|c|}{ Hasil Pengujian Siang Hari } & \multicolumn{2}{c|}{ Hasil Pengujian Malam Hari } \\
\cline { 2 - 5 } & $a\left(^{\circ}\right)$ & Eror (\%) & $a\left(^{\circ}\right)$ & Eror (\%) \\
\hline 0 & 0 & 0.0 & 0.0 & 0.0 \\
\hline 10 & 10 & 0 & 10 & 0 \\
\hline-10 & -10 & 0 & -9 & 10.0 \\
\hline 20 & 20 & 0 & 20 & 0 \\
\hline-20 & -20.5 & 5.0 & -20 & 0 \\
\hline 30 & 30 & 0 & 30.9 & 10 \\
\hline-30 & -30.55 & 3.3 & 30.25 & 3.3 \\
\hline 40 & 40.4 & 2.5 & 42.45 & 10 \\
\hline-40 & -40 & 0 & 39.25 & 10 \\
\hline
\end{tabular}

\subsection{Pengujian FSM Pada Robot}

\subsubsection{Pengujian State}

\section{Wander}

Wander adalah gerakan robot yang dilakukan apabila robot tidak menemukan bola setelah berputar $360^{\circ}$. Gerakan wander terdiri dari 3 gerakan, yaitu gerakan mendekat ke gawang merah, gerakan maju $10 \mathrm{~cm}$, dan memindai bola dengan berputar $360^{\circ}$. Jika tidak ada bola maka robot akan melakukan gerakan maju $10 \mathrm{~cm}$ dan memindai secara berulang hingga menemukan bola. Secara terperinci, gerakan wander terbagi menjadi 3 bagian yaitu wander 1, wander 2, dan wander 3. Masing-masing wander memiliki tindakan yang berbeda-beda. Wander 1 dipanggil ketika robot tidak menemukan bola. Tindakannya yaitu dengan mencari gawang berwarna merah atau gawangnya sendiri. Wander 2 yaitu memindai bola $360^{\circ}$, apabila bola tidak ada akan memanggil wander 3 . Sedangkan wander 3 yaitu meluruskan gawang biru, apabila sudah lurus, robot akan maju $10 \mathrm{~cm}$. Saat maju $10 \mathrm{~cm}$ robot juga diberikan tindakan memindai. Wander 2 dan wander 3 tersebut yang akan membentuk loop tertutup hingga robot menemukan bola. Gambar 12 merupakan proyeksi posisi robot dengan posisi awal dan akhir robot yang membutuhkan rata-rata waktu $21.4 \pm 32.6$ detik.

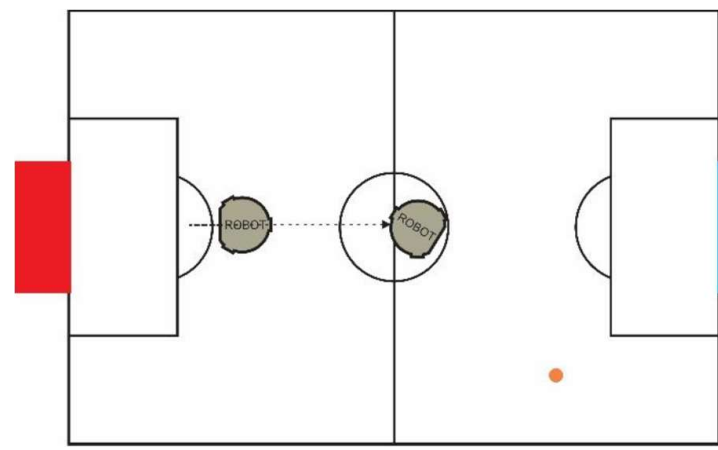

(a)

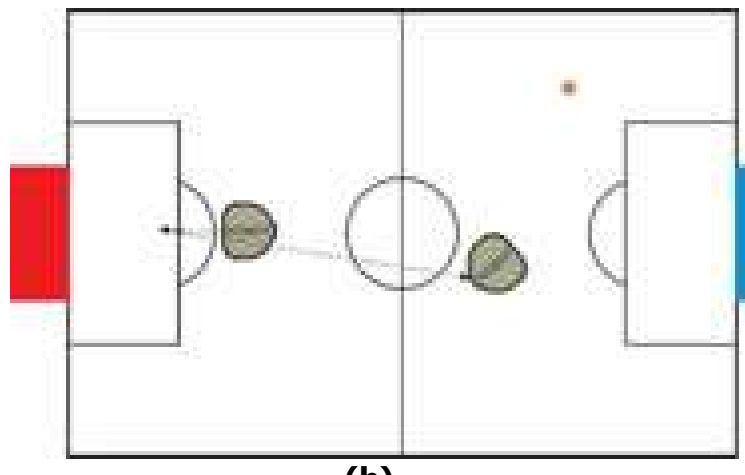

(b)

Gambar 12. Proyeksi posisi robot dan waktu wander (a) posisi awal dan (b) posisi akhir

Pengujian memindai bola dilakukan sebanyak 5 kali dari posisi awal robot hingga posisi akhir robot dengan rata-rata waktu \pm 8.22 detik, seperti pada Tabel 3 . Pengujian ini untuk mengetahui robot dapat maju dan berhenti pada jarak yang ditentukan, yaitu pada jarak 15 
$\mathrm{cm}$. Pada proses behenti tersebut diberikan dalam rentang berhenti, yaitu dari jarak $0 \mathrm{~cm}$ sampai dengan $15 \mathrm{~cm}$.

Tabel 3. Pengujian memindai bola

\begin{tabular}{|l|l|l|}
\hline Posisi awal robot & Posisi akhir robot & Rata-rata waktu (detik) \\
\hline
\end{tabular}

2. Gerakan robot mendapatkan posisi lurus terhadap bola

Pada saat robot menemukan bola pada posisi sudut dari $40^{\circ}$ hingga $40^{\circ}$ maka robot akan melakukan gerakan hingga mendapatkan posisi yang lurus terhadap bola, yaitu pada sudut robot terhadap bola antara sudut $-5^{0}$ hingga $5^{0}$. Tabel 4 merupakan hasil pengujian gerakan robot mendapatkan posisi lurus terhadap bola dengan melakukan gerakan ke arah kanan dan ke kiri dengan rata-rata waktu masing-masing 7.04 detik dan 6.54 detik.

Tabel 4. Pengujian luruskan bola

\begin{tabular}{|c|c|c|c|}
\hline Gerakan lurus ke- & Posisi awal robot & Posisi akhir robot & Rata-rata waktu (detik) \\
\hline Kanan & & \\
\hline
\end{tabular}




\section{Mencari gawang}

Untuk mencari gawang menggunakan tracking object berdasarkan warna, yaitu warna biru. Pada saat robot mendapatkan bola maka robot akan melakukan kondisi berikutnya, yaitu mencari gawang. Pada Tabel 5 diketahui bahwa robot membutuhkan rata-rata waktu sebesar 8.43 detik untuk mencari posisi gawang. Setelah mendapatkan posisi gawang maka robot melakukan gerakan maju pada posisi dengan jarak 30cm, seperti pada Gambar 13.

Setelah mendapatkan posisi gawang maka robot akan melakukan gerakan untuk mendapatkan posisi lurus terhadap gawang untuk melakukukan tendangan. Tabel 6 diketahui bahwa posisi robot terhadap bola tidak sama dengan $0^{\circ}$. Untuk melakukan gerakan robot mendapatkan posisi robot terhadap bola pada sudut $0^{0}$ membutuhkan rata-rata waktu sebesar 7.1 detik.

Tabel 5. Pengujian mencari gawang

\begin{tabular}{|c|c|c|}
\hline Posisi awal robot & Rata-rata waktu (detik) \\
\hline & & \\
\hline
\end{tabular}

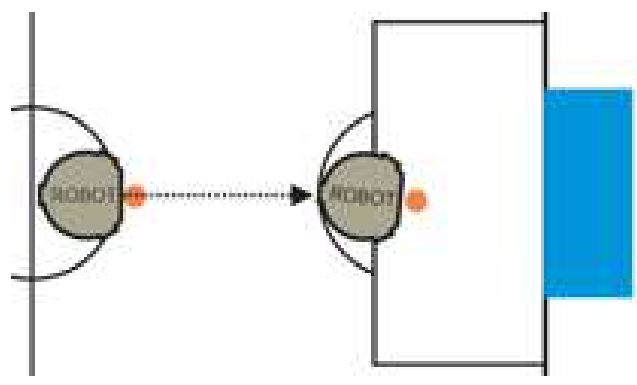

Gambar 13. Proyeksi maju ke gawang dan posisi gawang 
Tabel 6. Proyeksi lurus gawang

\begin{tabular}{|c|c|c|c|}
\hline \multicolumn{2}{|c|}{ Posisi awal robot } & $\begin{array}{c}\text { Rata-rata waktu } \\
\text { (detik) }\end{array}$ \\
\hline & & \\
\hline
\end{tabular}

4. Menendang bola

Pada saat robot telah mendapatkan posisi antara robot dengan gawang pada jarak $30 \mathrm{~cm}$ maka robot akan melakukan tindakan menendang bola. Gambar 14 diketahui posisi awal dan akhir bola pada saat robot melakukan gerakan menendang bola.

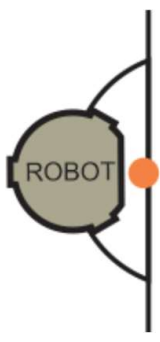

(a)

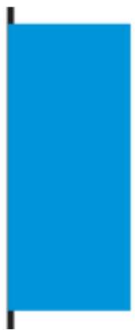

(1)

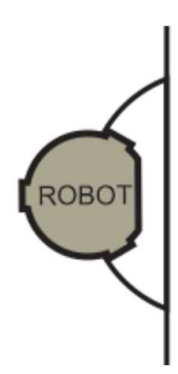

(b)

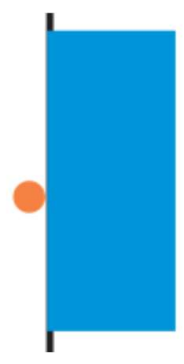

)

Gambar 14. Proyeksi bola pada saat (a) sebelum dilakukan tendangan (b) setelah dilakukan tendangan

\subsubsection{Pengujian keseluruhan}

Pengujian robot menggunakan trayektori yang dibagai menjadi lima jenis pengujian berdasarkan posisi bola yang berbeda-beda masing-masing dilakukan percobaan sebanyak 10kali di lapangan pengujian. Sehingga setiap pengujian tersebut dapat diamati melalui trayektori pada Gambar 15, bagaimana robot melakukan misi pada keadaan yang berbeda-beda. Tabel 7 merupakan data tingkat keberhasilan robot dan waktu yang dibutuhkan robot untuk menjalankan misi pada 5 kali percobaan.

Tabel 7. Hasil pengujian FSM pada Robot

\begin{tabular}{|c|c|c|}
\hline Pengujian ke - & Waktu rata-rata (detik) & Tingkat keberhasilan (\%) \\
\hline 1 & \pm 12.4 & 100 \\
\hline 2 & \pm 24.6 & 100 \\
\hline 3 & \pm 37.8 & 80 \\
\hline 4 & \pm 15.8 & 70 \\
\hline 5 & \pm 55.6 & 80 \\
\hline Rata-rata & \pm 29.24 & 86 \\
\hline
\end{tabular}




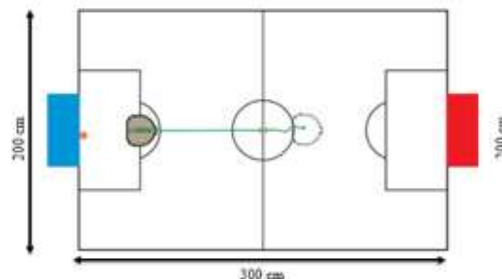

(a)

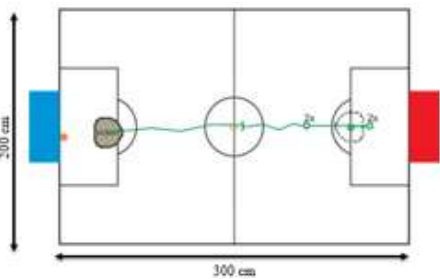

(b)

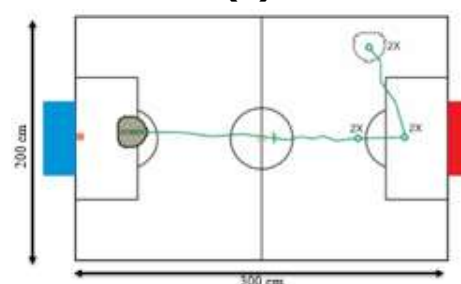

(c)

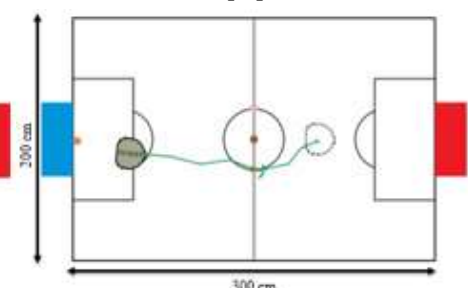

(d)

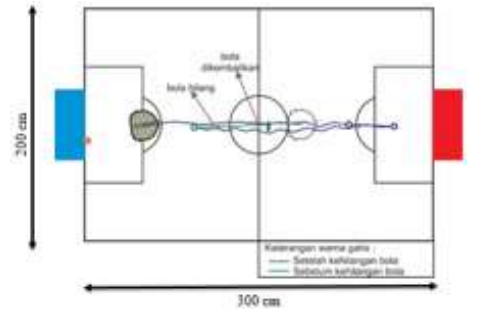

(e)

Gambar 15. Trayektori (a) pengujian 1 (b) pengujian 2 (c) pengujian 3 (d) pengujian 4 (e) pengujian 5

Pada Gambar 15(a) merupakan pengujian pertama di mana kondisi lapangan tidak obstacle sehingga dapat diketahui bahwa robot dapat menemukan bola dan posisi gawang dalam jangka waktu rata-rata \pm 12.4 detik. Pengujian pertama mencapai tingkat keberhasilan sebesar $100 \%$. Pengujian kedua dilakukan seperti Gambar 15(b) di mana robot bergerak untuk menemukan bola dengan melakukan gerakan wander dan dapat berjalan dengan sempurna hingga menendang bola membutuhkan jangka waktu rata-rata \pm 24.6 detik.

Pengujian kedua mencapai tingkat keberhasilan sebesar 100\%. Pengujian ketiga pada Gambar 15(c) robot melakukan gerakan $360^{\circ}$ untuk meminda bola. Namun, tidak menemukan bola kemudian melakukan gerakan wander dan dapat menemukan bola yang berada di tengah lapangan. Setelah menemukan bola, robot dapat melakukan gerakan yang sempurna hingga menendang bola dalam jangka waktu rata-rata \pm 37.8 detik. Pengujian keempat pada Gambar 15(d) robot melakukan gerakan cukup mudah karena tidak diperlukan wander karena bola terlihat saat robot memindai bola. Maka, robot bergerak hingga menendang ke gawang dalam jangka waktu rata-rata \pm 15.8 detik.

Pengujian kelima Gambar 15(e) robot melakukan gerakan awal yang sempurna ketika mendapatkan bola. Pada saat kehilangan bola maka robot melakukan pemindaian ulang. Apabila tidak ada bola maka robot akan melakukan gerakan wander. Untuk menyelesaikan tugas hingga menendang bola robot membutuhkan jangka waktu rata-rata \pm 55.6 detik. Berdasarkan pengujian keseluruhan pada Tabel 7, diketahui bahwa waktu rata-rata keseluruhan robot dapat menjalankan misi dengan kondisi yang berbeda-beda selama \pm 29.24 detik dengan tingkat keberhasilan keseluruhan sebesar $86 \%$. Faktor kegagalan pada pengujian keseluruhan terjadi karena robot kehilangan bola di depan gawang pada pengujian ke tiga hingga pengujian ke lima. 


\section{KESIMPULAN}

Penelitian menggunakan finite state machine (FSM) sebagai metode kontrol terdiri dari beberapa keadaan yang saling terhubung oleh sensor. Metode kontrol ini sangat baik digunakan untuk mengontrol robot sepak bola beroda dengan tingkah laku yang terstruktur dan terdiri dari beberapa banyak perilaku kecil. Pada penelitian ini, robot dapat mendeteksi objek berupa gawang dan bola berdasarkan warna dengan intensitas cahaya lingkungan pada kondisi siang dan malam masing-masing sebesar 113 lux dan 1213 lux. Sehingga, robot dapat mendeteksi jarak dan sudut antara robot dengan target pada jarak $20-60 \mathrm{~cm}$ dengan sudut deteksi -40 derajat hingga 40 derajat. Implementasi metode FSM pada robot dilakukan pengujian sebanyak 5 kali dengan masing-masing pengujian dilakukan 10 kali percobaan. Hasil menunjukkan bahwa robot dapat menyelesaikan seluruh misi pada keseluruhan pengujian dengan waktu rata-rata 29.24 detik dengan tingkat keberhasilan sebesar $86 \%$. Faktor kegagalan terjadi karena robot kehilangan bola pada saat didepan gawang. Untuk penelitian selanjutnya, FSM yang diterapkan pada setiap individu robot untuk navigasi harus diterapkan juga dalam tim dengan melibatkan robot - robot yang lain. Tujuannya adalah perubahan strategi secara tim baik untuk menyerang, bertahan atau menahan bola perlu dilakukan dalam rangka memenangkan pertandingan.

\section{DAFTAR RUJUKAN}

Al Tahtawi, A. R., Somantri, Y., \& Haritman, E. (2016). Design and Implementation of PID Control-based FSM Algorithm on Line Following Robot. Jurnal Teknologi Rekayasa, $1(1), 23-60$.

Aleluya, E. R. M., Zamayla, A. D., \& Tamula, S. L. M. (2018). Decision-making system of soccerplaying robots using finite state machine based on skill hierarchy and path planning through Bezier polynomials. Procedia Computer Science, 135, 230-237. https://doi.org/10.1016/j.procs.2018.08.170

Ardhiansyah, T., Syarifuddin, I., Naufal, M. R., Pramono, Y., Hartatik, O. T., \& Mustaqim, I. (2017). Pergerakan Otomatis Robot Sepak Bola Beroda Melalui Komunikasi dengan Referee Box Menggunakan Base Station. 5th Indonesian Syposium on Robotic System and Control, (pp. 82-86).

Dadios, E. P., \& Park, S. H. (2009). Real time robot soccer game event detection using finite state machines with multiple fuzzy logic probability evaluators. International Journal of Computer Games Technology, 2009(1). https://doi.org/10.1155/2009/375905

Damas, B., \& Lima, P. (2004). Stochastic Discrete Event Model Of A Multi-Robot Team Playing An Adversarial Game. The 5th IFAC/EURON Symposium on Intelligent Autonomous Vehicles - IAV2004, Portugal, (pp.1-6).

Fajar, S. D. (2017). Robot Soccer Beroda Berbasis Raspberry Pi 3 Sebagai Prototype ERSBI 2017. Universitas Sanata Dharma Yogyakarta.

Fiqhi, I. A. R. A., \& Joni, K. (2018). Sistem Deteksi Objek dan Posisi pada Robot Sepak Bola 
Beroda Middle Size pada Sistem Kamera Omni Vision dengan Scan Lines. The 6th Indonesian Symposium on Roboting System and Control (ISRSC), (pp. 54-58).

Haritman, E., \& Somantri, Y. (2009). Rancang Bangun Robot Pemindah Benda Dengan Penjejak Garis. Seminar Nasional Electrical, Informatics, and IIts Education, (pp. 8488).

Hartanto, M. I., Mutijarsa, K., \& Adiprawita, W. (2017). Sistem Koordinasi Berbasis Perilaku pada Robot Sepak Bola. 5th Indonesian Symposium on Robotic Systems and Control, (pp. 219-223).

Kurihara, N., Hayashi, R., \& Fujii, H. (2004). Intelligent Control of Autonomous Mobile Soccer. In RoboCup, (pp. 568-575).

Lou, Y., Chen, B., \& Shi, H. (2012). Decision making model based on state assessment and hierarchical FSM in robot soccer. IET Conference Publications, $2012(598$ CP), 756-759. https://doi.org/10.1049/cp.2012.1087

Naufal, M. R., Belga, R. I., Hartatik, O. T., Wicaksono, S. E., Wibowo, A. W. N., Pradana, A. W., \& Yatmono, S. (2018). Rancang Bangun Mekanik Ekspansi Robot Goalkeeper Sepak Bola Beroda Menggunakan Pneumatik. The 6th Indonesian Symposium on Robotic Systems and Control (ISRSC), (pp. 99-103).

Pratama, R. W., Ananda, G. R., Putra, Y. D., Mahadika, P., Maulana, Y., \& Sistem, A. D. (2017). Rancang Bangun Robot Sepak Bola Beroda. 5th Indonesian Symposium on Robotic System and Control, (pp. 149-151).

Putra, H., Fanshuri, R., \& Radar, S. S. (2018). Metode Pendeteksi Bola dan Gawang pada Robot Sepak Bola Beroda. The 6th Indonesian Symposium on Robotics System and Control (ISRSC), (pp. 114-116).

Rizaldi, M. I., Rismanto, R., \& Ekojono. (2017). Implementasi Finite State Machine Pada Game "Save the Animals ."1-7.

Suhri, I. N. (2017). Robot Soccer Beroda Dengan Metode Behaviour based Control. In Digital Repository Universitas Jember.

Wirakusuma, T., \& Sujono. (2018). Perancang Strategi Pergerakan Robot Sepakbola Beroda Untuk Menghidari Lawan. Jurnal Maestro, 1(2), 317-322.

Yulianto, A., \& Handoyo, H. P. (2012). Penerapan Behavior-Based Control dan Fuzzy Logic Controller pada Sistem Navigasi Robot Soccer. CENTRE Civil and Electrical Engineering Journal, 71 , 16-23.

Zhu, D., Biswas, J., \& Veloso, M. (2015). AutoRef: Towards Real-Robot Soccer Complete Automated Refereeing. RoboCup 2014, 1(3), 419-430. 